\title{
Zedoarondiol Inhibits Platelet-Derived Growth Factor-Induced Vascular Smooth Muscle Cells Proliferation via Regulating AMP-Activated Protein Kinase Signaling Pathway
}

\author{
Huimin Mao $\mathrm{O}^{\mathrm{a}, \mathrm{b}, \mathrm{c}}$ Tianqi Tao ${ }^{\mathrm{b}}$ Dandan Song ${ }^{\mathrm{b}}$ Mi Liu ${ }^{\mathrm{b}, \mathrm{c}}$ Xiaoren Wang ${ }^{\mathrm{b}}$ Xiuhua Liu ${ }^{\mathrm{b}}$ \\ Dazhuo Shic
}

aGraduate School, Beijing University of Chinese Medicine, Beijing, bDepartment of Pathophysiology, Chinese PLA General Hospital, Beijing, 'Cardiovascular Disease Center, Xiyuan Hospital, China Academy of Chinese Medical Sciences, Beijing, China

\section{Key Words}

Zedoarondiol • Vascular smooth muscle cell • Proliferation • AMP-activated protein kinase

\begin{abstract}
Background/Aims: Vascular smooth muscle cells (VSMCs) proliferation contributes significantly to atherosclerosis and in-stent restenosis. Platelet-derived growth factor-BB (PDGF-BB) plays a vital role in VSMCs proliferation. Zedoarondiol, a sesquiterpene lactone compound, has an anti-inflammatory activity. However, the role of zedoarondiol in PDGFBB-mediated VSMCs proliferation remains unclear. In this study, we investigated the effects of zedoarondiol on PDGF-BB-induced VSMCs proliferation and explored the possible mechanisms. Methods: The inhibitory effects of zedoarondiol on PDGF-BB-induced VSMCs proliferation were evaluated by direct cell counting and the Cell Counting Kit-8 (CCK-8) assay. DNA synthesis was examined by bromodeoxyuridine (BrdU) incorporation assay. Cell cycle was assessed by propidium iodide staining. Western blotting was performed to determine the expression of cyclin-dependent kinase 2 (CDK2), cyclin E, p53, p21, total and phosphorylated adenosine monophosphate-activated protein kinase (AMPK), acetyl CoA carboxylase (ACC), mammalian target of rapamycin (mTOR), and p70 ribosomal protein 56 kinase (p70S6K). Results: Zedoarondiol suppressed PDGF-BB-induced VSMCs proliferation and DNA synthesis, and induced cell cycle arrest in G0/G1 phase. In addition, zedoarondiol activated AMPK and ACC, inhibited the phosphorylation of mTOR and p70S6K, increased the expression of p53 and p21, and decreased the expression of CDK2 and cyclin E. Compound C (an AMPK inhibitor) abrogated, whereas 5 -aminoimidazole-4-carboxamide 1 - $\beta$-ribofuranoside (AICAR, an AMPK activator) enhanced zedoarondiol-mediated inhibition of VSMCs proliferation and DNA synthesis. Conclusion: Zedoarondiol inhibits PDGF-BB-induced VSMCs proliferation via AMPK-mediated down-regulation of the mTOR/p70S6K pathway and up-regulation of the p53/p21 pathway. These findings suggest that zedoarondiol might be a promising compound against atherosclerosis and in-stent restenosis.

(C) 2016 The Author(s)

Published by S. Karger AG, Basel
\end{abstract}

Dazhuo Shi, M.D., Ph.D. and Xiuhua Liu, M.D., Ph.D.

KARGER
Cardiovascular Disease Center, Xiyuan Hospital, China Academy of Chinese Medical Sciences, Beijing 100091 (China); Department of Pathophysiology, Chinese PLA General Hospital, 28 Fuxing Road, Haidian District, Beijing 100853, Beijing 100853 (China)

E-Mail shidazhuo11@sina.com/xiuhualiu98@163.com 


\section{Introduction}

Vascular smooth muscle cells (VSMCs) proliferation and migration contribute significantly to the development of atherosclerosis (AS) [1] and restenosis (RS) after percutaneous coronary intervention [2]. VSMCs proliferation and migration can be induced by cytokines and growth factors released after vascular injury, including platelet-derived growth factors (PDGFs) [3, 4], interleukin-1 [5], tumor necrosis factor (TNF)- $\alpha$ [6], and angiotensin II [7]. PDGFs, especially PDGF-BB, are considered as the most potent mitogens stimulating VSMCs proliferation [8]. PDGF-BB initiates a series of biological effects associated with VSMCs proliferation via activating intracellular signal transduction pathways, including mitogen-activated protein kinase (MAPK) [9], phosphoinositide 3-kinase/protein kinase B (PI3K/Akt) [10], Rho kinase (ROCK) [11] and mammalian target of rapamycin (mTOR) [12] pathways. Hence, inhibition of PDGF-stimulated VSMCs proliferation is a promising strategy to attenuate $\mathrm{AS}$ and RS.

Zedoariae rhizoma (Curcuma zedaria Roscoe, e'zhu in Chinese) is a herbal drug belonging to the Zingiberaceae family. The main bioactive constituents of Zedoariae rhizoma are diarylheptanoids and sesquiterpenoids [13], which have pleiotropic pharmacological effects, including anti-inflammatory, antioxidant, and anti-proliferative activities [14-16]. Our previous study showed that stents coated with Zedoariae rhizoma essential components (zedoary essential components, ZEC), mainly including sesquiterpenoids, inhibited neointimal hyperplasia in a porcine coronary arterial balloon-injury model [17], indicating that essential components of Zedoariae rhizoma play an important role in regulating VSMCs proliferation. Zedoarondiol (Fig. 1), a sesquiterpene lactone, is the main bioactive compound extracted from ZEC and has been reported to attenuate lipopolysaccharide (LPS)-induced inflammation in murine macrophages by suppressing nuclear factor-kappa B (NF- $\kappa$ B) pathway [18] and reduce D-galactosamine-induced liver injury in mice [19, 20]. However, little is known about the role of zedoarondiol in regulating VSMCs proliferation.

Adenosine monophosphate-activated protein kinase (AMPK), consisting of a catalytic subunit $(\alpha)$ and two regulator subunits $(\beta$ and $\gamma$ ), plays a key role in energy metabolism and acts as a cellular fuel sensor [21]. AMPK is activated by cellular stress including ischemia, hypoglycemia, hypoxia, and oxidative stress, which is associated with an increased adenosine monophosphate (AMP)/adenosine triphosphate (ATP) ratio [22]. Accumulating evidence shows that AMPK activation suppresses VSMCs proliferation and attenuates neointima formation in vascular injury models [23-25], indicating AMPK as a novel therapeutic target for AS and RS [26]. Cell growth inhibition by AMPK activation is mainly attributed to activation of the p53/p21 pathway followed by cell cycle arrest in G0/G1 phase [27] and inhibition of the mTOR signaling pathway [28].

In the current study, we hypothesized that zedoarondiol inhibits PDGF-BB-induced VSMCs proliferation via AMPK activation. To test this hypothesis, we investigated the effects of zedoarondiol on PDGF-BB-induced VSMCs proliferation and AMPK pathway, to provide the evidence for utility of zedoarondiol in preventing and treating AS and RS.

\section{Materials and Methods}

\section{Materials}

Zedoarondiol was kindly provided by Dalian Institute of Chemical Physics, Chinese Academy of Sciences (Dalian, Liaoning, China). Recombinant human PDGF-BB was purchased from R\&D Systems (Minneapolis, MN, USA). Compound C was obtained from CalBiochem (San Diego, CA, USA). 5-aminoimidazole-4-carboxamide 1 - $\beta$-ribofuranoside (AICAR) was purchased from Sigma-Aldrich (St. Louis, MO, USA). Dulbecco's modified Eagle medium (DMEM) was purchased from Gibco (Grand Island, NY, USA). Fetal bovine serum (FBS) was obtained from Sijiqing Biochemistry Technique Co., Ltd. (Hangzhou, Zhejiang, China). The Cell Counting Kit-8 (CCK-8) kit was purchased from Dojindo Laboratories (Kumamoto, Japan). The Bromodeoxyuridine (BrdU) Cell Proliferation ELISA Kit was obtained from Roche Diagnostics (Mannheim, Germany). The Cell 


\section{Cellular Physiology Cell Physiol Biochem 2016;40:1506-1520 \begin{tabular}{l|l|l|}
\hline DOI: 10.1159/000453201 & $\begin{array}{l}\text { C) 2016 The Author(s). Published by S. Karger AG, Basel } \\
\text { www.karger.com/cpb }\end{array}$
\end{tabular} \\ Mao et al.: Zedoarondiol Inhibits VSMCs Proliferation via AMPK}

Cycle and Apoptosis Analysis Kit was purchased from Beyotime Biotechnology Company (Shanghai, China). The Annexin V/fluorescein isothiocyanate (FITC) Apoptosis Direction Kit was purchased from KeyGen Biological Engineering Company (Nanjing, Jiangsu, China). The enhanced chemiluminescence (ECL) kit was obtained from Santa Cruz Biotechnology (Santa Cruz, CA, USA). Antibodies against AMPKa (2532), phospho-AMPKa ${ }^{\text {Thr172 }}$ (2535),

Fig. 1. Chemical structure of zedoarondiol.

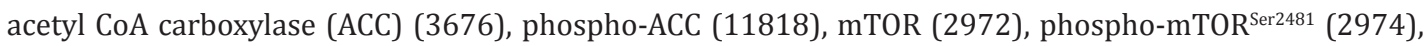
p70S6K (2708), phospho-p70S6 $\mathrm{K}^{\text {Thr389 }}$ (9234), p53 (2524), and glyceraldehyde 3-phosphate dehydrogenase (GAPDH) were purchased from Cell Signaling Technology (Danvers, MA, USA). Antibodies against cyclindependent kinase (CDK) 2 (sc-6248), cyclin E (sc-481) and p21 (sc-397) were purchased from Santa Cruz Biotechnology (Santa Cruz, CA, USA). The antibody for SM $\alpha$-actin (ab5694) was purchased from Abcam (Cambridge, MA, USA). Horseradish peroxidase (HRP)-conjugated goat anti-rabbit immunoglobulin G (IgG) and anti-mouse IgG were obtained from Epitomics (Burlingame, CA, USA).

\section{Cell culture and experimental protocols}

Primary VSMCs were obtained from thoracic aortas of male Sprague-Dawley rats (120 to $160 \mathrm{~g}$ ), as described previously [29]. Briefly, the aorta was isolated and the adventitias were stripped off. Tunica media was isolated from the aorta, minced, and cultured in DMEM supplemented with 10\% FBS and 1\% penicillin/ streptomycin (Gibco, MD, USA) in a humidified atmosphere with $5 \% \mathrm{CO}_{2}$ at $37^{\circ} \mathrm{C}$. The identity and purity of VSMCs were confirmed by positive staining of SM $\alpha$-actin. Passages 4-8 of VSMCs were used in this study. To assess the effect of zedoarondiol on VSMCs proliferation in the absence of PDGF-BB, cells were treated with zedoarondiol $(5,10,20$, and $40 \mu \mathrm{g} / \mathrm{mL})$ for $24 \mathrm{~h}$ in serum-free media. To evaluate the effect of zedoarondiol on PDGF-BB-induced VSMCs proliferation, VSMCs were pretreated with zedoarondiol $(5,10$, and $20 \mu \mathrm{g} / \mathrm{mL})$ for $24 \mathrm{~h}$ in serum-free media and then stimulated with $20 \mathrm{ng} / \mathrm{mL}$ PDGF-BB for another $24 \mathrm{~h}$. To explore the role of AMPK in zedoarondiol-mediated anti-proliferative effects in VSMCs, cells were divided into six groups: (1) control group: VSMCs were cultured routinely for $48 \mathrm{~h}$; (2) Zed group: VSMCs were treated with zedoarondiol $(20 \mu \mathrm{g} / \mathrm{mL})$ in serum-free media for $48 \mathrm{~h}$; (3) PDGF group: VSMCs were cultured routinely for $24 \mathrm{~h}$, and then stimulated with PDGF-BB $(20 \mathrm{ng} / \mathrm{mL})$ for another $24 \mathrm{~h}$; (4) PDGF+Zed group: VSMCs were pretreated with zedoarondiol $(20 \mu \mathrm{g} / \mathrm{mL})$ in serum-free media for $24 \mathrm{~h}$, and then stimulated with PDGFBB $(20 \mathrm{ng} / \mathrm{mL}$ ) for another $24 \mathrm{~h}$; (5) PDGF+Zed+compound C (an AMPK inhibitor) group: VSMCs were pretreated with zedoarondiol $(20 \mu \mathrm{g} / \mathrm{mL})$ and compound C $(10 \mu \mathrm{M})$ for $24 \mathrm{~h}$, and stimulated with PDGF-BB $(20 \mathrm{ng} / \mathrm{mL}$ ) for another $24 \mathrm{~h}$; (6) PDGF+Zed+AICAR (an AMPK activator) group: VSMCs were pretreated with zedoarondiol $(20 \mu \mathrm{g} / \mathrm{mL})$ and AICAR $(0.5 \mathrm{mM})$ for $24 \mathrm{~h}$, and stimulated with PDGF-BB $(20 \mathrm{ng} / \mathrm{mL})$ for another $24 \mathrm{~h}$. Experimental protocols were approved by the Institutional Animal Care and Use Committee of the Chinese PLA General Hospital, and complied with the Animal Management Rule of the Ministry of Health, People's Republic of China (Document 55, 2001).

\section{Cell counting}

The cells were seeded in 6-well plates at a density of $2 \times 10^{5}$ cells/well. After experimental treatment, cells were harvested and stained with $0.4 \%$ trypan blue dye solution. The number of cells not stained with trypan blue was determined using a hemocytometer.

CCK-8 assay

The CCK-8 assay was conducted according to the manufacturer's instructions to determine VSMCs proliferation. VSMCs were seeded in 96-well plates at a density of $5 \times 10^{3}$ cells/well. After experimental treatment, $10 \mu \mathrm{L}$ of CCK-8 was added to each well for $2 \mathrm{~h}$ at $37^{\circ} \mathrm{C}$. Absorbance was measured at $450 \mathrm{~nm}$ using a microplate reader (Tecan Infinite f200 Pro, Tecan Group Ltd, Männedorf, Switzerland).

DNA synthesis assay

DNA synthesis was assessed by BrdU incorporation according to the manufacturer's instructions. Cells were seeded in 96-well plates at a density of $1 \times 10^{4}$ cells/well. BrdU (10 $\mu \mathrm{L} /$ well) was added for the last 4 


\section{Cellular Physiology Cell Physiol Biochem 2016;40:1506-1520 \begin{tabular}{l|l} 
and Biochemistry Published online: December 21, 2016 & $\begin{array}{l}\text { C } 2016 \text { The Author(s). Published by S. Karger AG, Basel } \\
\text { www.karger.com/cpb }\end{array}$
\end{tabular} \\ Mao et al.: Zedoarondiol Inhibits VSMCs Proliferation via AMPK}

$\mathrm{h}$ of the experiment. After removing the culture medium, FixDenat (200 $\mu \mathrm{L} /$ well) was added, followed by incubation with anti-BrdU-POD (100 $\mathrm{L}$ /well) for $90 \mathrm{~min}$ at room temperature. The fixed cells were washed twice with PBS and incubated with $100 \mu \mathrm{L} /$ well substrate solution for $15 \mathrm{~min}$. Absorbance was measured at $492 \mathrm{~nm}$ using an ELISA reader (Tecan Infinite f200 Pro, Tecan Group Ltd, Männedorf, Switzerland).

\section{Cell cycle analysis}

Cell cycle was analyzed according to the manufacturer's protocol of Cell Cycle and Apoptosis Analysis Kit. VSMCs were seeded in 6-well plates at a density of $2 \times 10^{5}$ cells/well. Cells were harvested and fixed in cold $70 \%$ methanol overnight at $-20^{\circ} \mathrm{C}$. Afterwards, the cells were washed twice with PBS and incubated with propidium iodide (PI) staining buffer $\left(100 \mu \mathrm{g} / \mathrm{mL}\right.$ PI and $100 \mu \mathrm{g} / \mathrm{mL}$ RNase A) for $30 \mathrm{~min}$ at $37^{\circ} \mathrm{C}$. FACSCalibur flow cytometer (BD Biosciences, Franklin Lakes, NJ, USA) was used in the analysis.

\section{Annexin V and PI double-staining assay}

VSMCs were seeded in 6-well plates at a density of $1 \times 10^{5}$ cells/well. After treatment, cells were harvested with $0.25 \%$ trypsin and washed twice with cold PBS. Cells were subjected to an apoptosis assay, using an Annexin V and PI apoptosis kit according to the manufacturer's instructions. Cell preparations were resuspended in $500 \mu \mathrm{L}$ binding buffter, labeled with Annexin V and PI, and analyzed on a FACSCalibur flow cytometer (BD Biosciences, Franklin Lakes, NJ, USA).

\section{Western blot analysis}

Cells were collected and lysed in lysis buffer, as previously described [30]. After quantifying protein concentration using the bicin-choninic acid (BCA) method [31], $80 \mu \mathrm{g}$ of protein was resolved on $8-12 \%$ sodium dodecyl sulfate-polyacrylamide gels for electrophoresis, and electrophoretically transferred to nitrocellulose membranes. The membranes were blocked with $5 \%$ bovine serum albumin (BSA) in Trisbuffered saline containing $0.1 \%$ Tween 20 (TBST) for $1 \mathrm{~h}$ at room temperature, incubated with primary antibodies against CDK2, cyclin E, p21 (all 1:200 diluted), AMPK, p-AMPK, ACC, p-ACC, mTOR, p-mTOR ${ }^{\text {ser2481, }}$ p70S6K, p-p70S6K $\mathrm{K}^{\mathrm{Th} 389}$, p53, and GAPDH (all 1:1000 diluted) overnight at $4^{\circ} \mathrm{C}$, and finally probed with corresponding horseradish peroxidase (HRP)-conjugated secondary antibodies for $1 \mathrm{~h}$. Protein bands were detected using an ECL kit and the optical density of bands was quantified using Image-Pro Plus (Roper Industries, New York, NY, USA). Protein expression was normalized to GAPDH.

\section{Statistical analyses}

SPSS 17.0 software (IBM, Chicago, IL, USA) was applied for statistical analyses. Data were expressed as mean \pm standard deviation (SD). Differences were evaluated by one-way analysis of variance (ANOVA) followed by Tukey's post-hoc test. A value of $P<0.05$ was considered statistically significant.

\section{Results}

\section{Zedoarondiol inhibits PDGF-BB-induced VSMCs proliferation}

Previous studies have indicated that zedoarondiol inhibits D-galactosamine-induced cytotoxicity in primary cultured rat hepatocytes and attenuates inflammation by suppressing $\mathrm{NF}-\kappa \mathrm{B}$ pathway in macrophages [18-20]. In the present study, we first evaluated the effect of zedoarondiol on VSMCs in the absence of PDGF-BB. Zedoarondiol (5, 10, 20, and $40 \mu \mathrm{g} /$ $\mathrm{mL}$ ) did not decrease VSMCs viability in the absence of PDGF-BB when compared with that in the control group ( $P>0.05$; Fig. $2 \mathrm{~A}$ ), indicating that zedoarondiol was not cytotoxic at the concentrations tested. Next, we examined the effect of zedoarondiol on PDGF-BB-induced VSMCs proliferation by direct cell counting. PDGF-BB (20 ng/mL) significantly increased the number of cells up to 1.5 fold $(P<0.05$ vs. control). Pretreatment with zedoarondiol decreased the number of cells in a dose-dependent manner ( $P<0.05$ vs. PDGF; Fig. 2B). We further investigated the inhibitory effect of zedoarondiol on VSMCs by the CCK-8 assay. Compared with control group, PDGF-BB (20 ng/mL) treatment significantly increased VSMCs proliferation up to 1.3 fold $(P<0.05)$. Compared with PDGF group, zedoarondiol pretreatment at 5 and $10 \mu \mathrm{g} / \mathrm{mL}$ had no effect on PDGF-BB-induced VSMCs proliferation $(P>$ 0.05). However, zedoarondiol at $20 \mu \mathrm{g} / \mathrm{mL}$ decreased PDGF-BB-induced VSMCs proliferation 
Fig. 2. Effects of zedoarondiol (Zed) on VSMCs viability and proliferation. (A) VSMCs were treated by zedoarondiol $(5,10,20$, and $40 \mu \mathrm{g} / \mathrm{mL}$ ) for $24 \mathrm{~h}$. (B) VSMCs were treated with zedoarondiol (5, 10,20 , and $40 \mu \mathrm{g} / \mathrm{mL}$ ) for $24 \mathrm{~h}$ and incubated with PDGF-BB (20 ng/ $\mathrm{mL}$ ) for another $24 \mathrm{~h}$. VSMCs proliferation was assessed by direct cell counting. (C) VSMCs were treated as in B. VSMCs proliferation was assessed by the CCK-8 assay. (D) VSMCs were pretreated with Zed $(20 \mu \mathrm{g} / \mathrm{mL})$, Zed+compound C (10 $\mu \mathrm{M})$ or Zed+AICAR (0.5 $\mathrm{mM}$ ) for $24 \mathrm{~h}$ and incubated with/without PDGF-BB (20 ng/mL) for a further $24 \mathrm{~h}$. VSMCs proliferation was assessed by direct cell counting. (E) VSMCs were treated as in D.

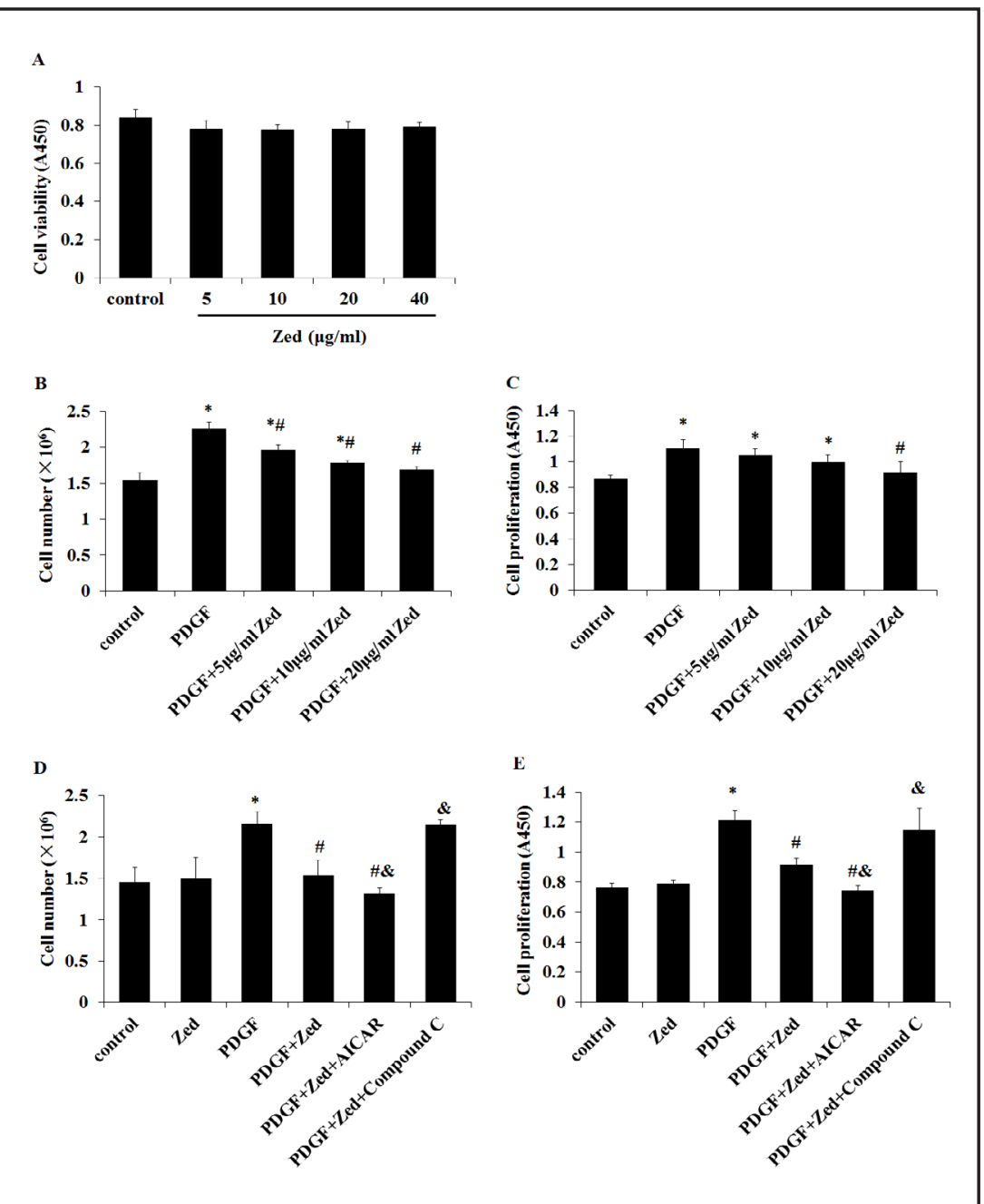
VSMCs proliferation was assessed by the CCK-8 assay. Data are expressed as mean \pm SD. $\mathrm{n}=6 .{ }^{*} P<0.05$ vs. control; ${ }^{\#} P<0.05$ vs. PDGF; ${ }^{\&} P<0.05$ vs. PDGF+Zed.

by $17 \%(P<0.05$ vs. PDGF; Fig. 2C). Our results indicated that zedoarondiol showed an inhibitory effect on PDGF-BB-induced VSMCs proliferation.

To determine whether the anti-proliferative effects of zedoarondiol on VSMCs were mediated by AMPK activation, cells were co-treated with AICAR (an AMPK activator) or compound C (an AMPK inhibitor). Compared with PDGF + Zed group, compound C (10 $\mu \mathrm{M})$ dramatically reversed zedoarondiol-mediated anti-proliferative effects on PDGF-BBstimulated VSMCs proliferation, resulting in a 63\% increase in cell number $(P<0.05)$. Notably, pretreatment with zedoarondiol $(20 \mu \mathrm{g} / \mathrm{mL})$ and AICAR $(0.5 \mathrm{mM})$ further decreased the number of cells by $14 \%(P<0.05$ vs. PDGF + Zed; Fig. 2D). Similar results were obtained from the CCK-8 assay. Compared with PDGF + Zed group, the addition of compound C increased VSMCs proliferation by $25 \%(P<0.05)$, whereas the additional AICAR treatment decreased VSMCs proliferation by $19 \%(P<0.05$; Fig. 2E).

\section{Zedoarondiol inhibits PDGF-BB-induced DNA synthesis in VSMCs}

We evaluated the effect of zedoarondiol on PDGF-BB-induced DNA synthesis in VSMCs by BrdU incorporation assay. PDGF-BB treatment increased DNA synthesis in VSMCs up to 1.57 fold $(P<0.05$ vs. control), whereas zedoarondiol pretreatment decreased PDGFBB-induced DNA incorporation in a concentration-dependent manner. When compared 


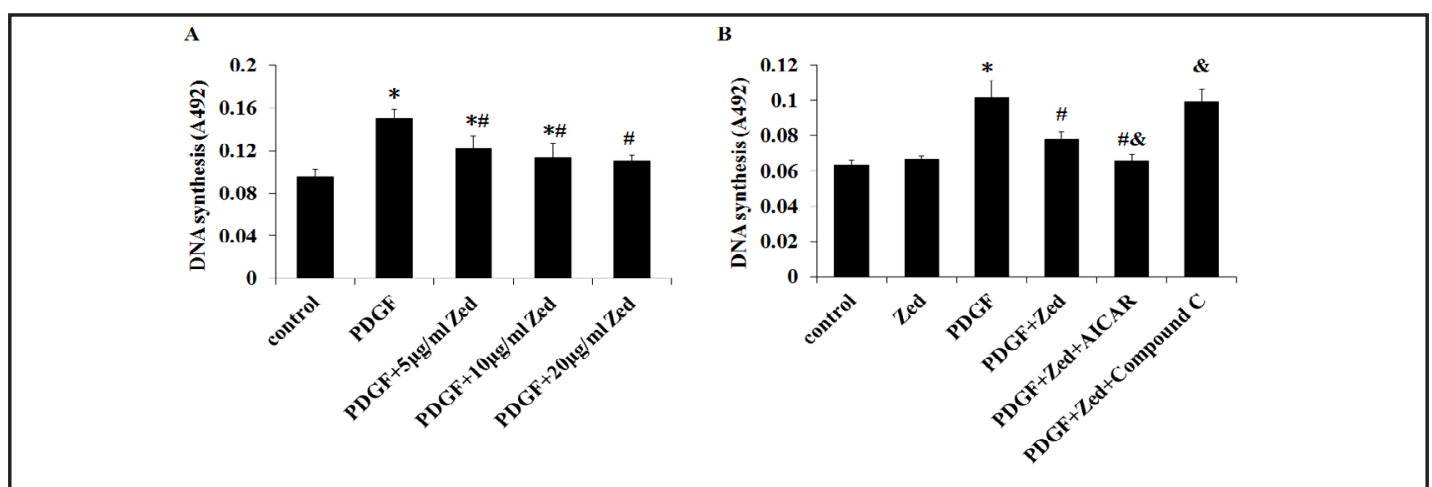

Fig. 3. Effects of zedoarondiol (Zed) on PDGF-BB-induced DNA synthesis in VSMCs, measured by BrdU incorporation assay. (A) VSMCs were treated with zedoarondiol $(5,10,20$, and $40 \mu \mathrm{g} / \mathrm{mL}$ ) for $24 \mathrm{~h}$ and incubated with PDGF-BB (20 ng/mL) for another $24 \mathrm{~h}$. (B) VSMCs were pretreated with Zed $(20 \mu \mathrm{g} / \mathrm{mL})$, Zed+compound C $(10 \mu \mathrm{M})$ or Zed+AICAR $(0.5 \mathrm{mM})$ for $24 \mathrm{~h}$ and incubated with/without PDGF-BB $(20 \mathrm{ng} /$ $\mathrm{mL}$ ) for a further $24 \mathrm{~h}$. Data are expressed as mean \pm SD. $\mathrm{n}=6 .{ }^{*} P<0.05$ vs. control; ${ }^{\#} P<0.05$ vs. PDGF; \& $P<0.05$ vs. PDGF+Zed.

Fig. 4. Zedoarondiol arrests VSMCs cell cycle in G0/G1 phase. VSMCs were pretreated with zedoarondiol $(5,10$, and $20 \mu \mathrm{g} /$ $\mathrm{mL}$ ) for $24 \mathrm{~h}$ followed by PDGF-BB (20 ng/mL) stimulation for another 24 h. Then, cells were stained with PI to determine DNA fluorescence and cell cycle distribution. (A) Representative cell cycle. (B) VSMCs in G0/G1 phase. (C) VSMCs in $\mathrm{S}$ phase. Data are expressed as mean \pm SD. $\mathrm{n}$ $=3 .{ }^{*} P<0.05$ vs. control; ${ }^{\#} P<0.05$ vs. PDGF.

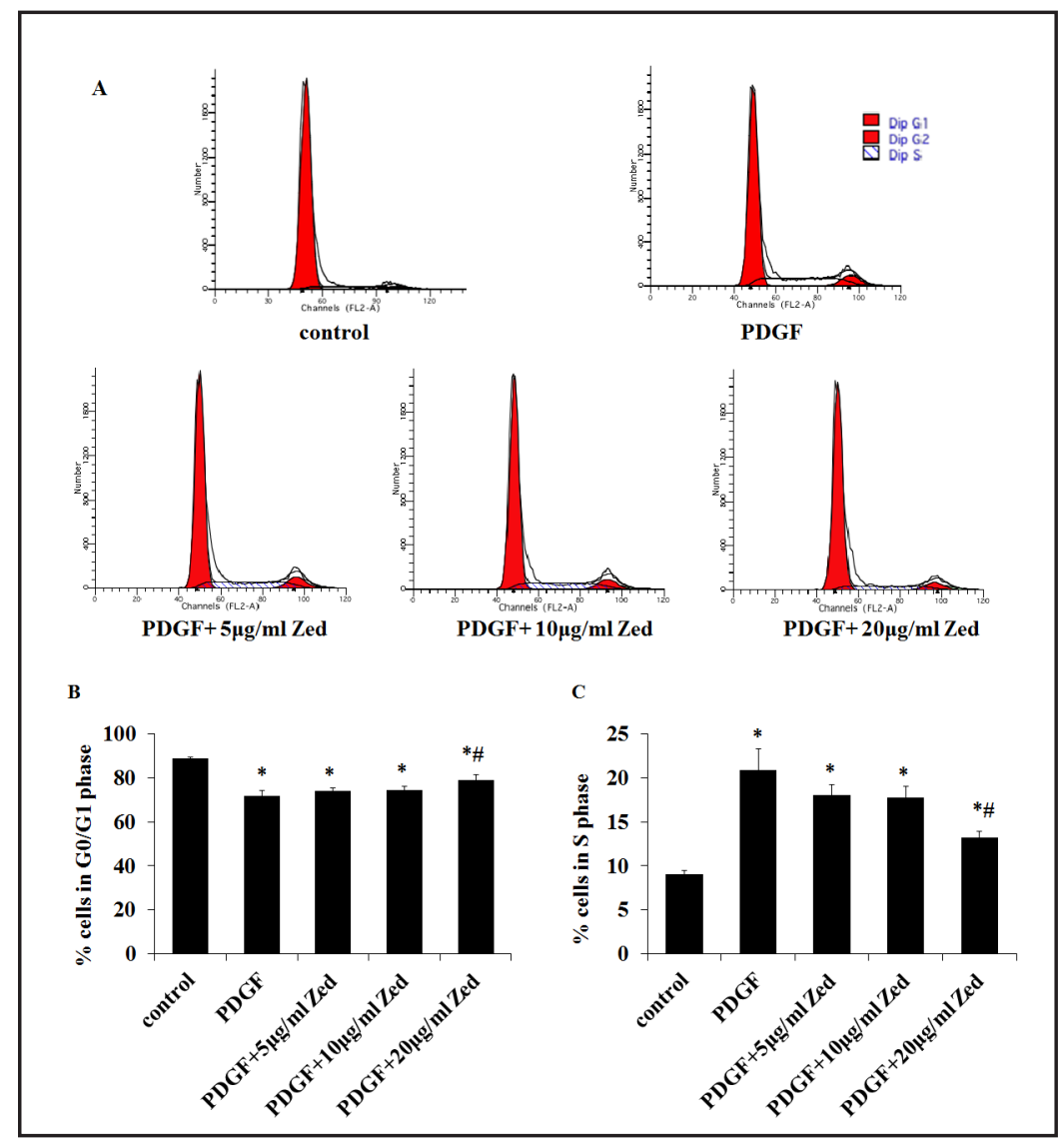

with PDGF group, zedoarondiol at 5, 10, and $20 \mu \mathrm{g} / \mathrm{mL}$ decreased PDGF-BB-induced DNA synthesis in VSMCs by $18.5 \%, 24.4 \%$, and $26.2 \%$, respectively $(P<0.05$; Fig. $3 A$ ).

Next, we explored the role of AMPK in zedoarondiol-mediated inhibition of DNA synthesis. As expected, pretreatment with zedoarondiol and compound $\mathrm{C}$ abolished zedoarondiol-induced inhibition of DNA synthesis under PDGF-BB conditions, showing a 51 $\%$ increase in DNA synthesis, as compared with PDGF+Zed group $(P<0.05)$. In contrast, pretreatment with zedoarondiol and AICAR displayed a greater inhibitory effect on DNA synthesis, revealing a further $15.59 \%$ decrease $(P<0.05$ vs. PDGF+Zed; Fig. 3B). 


\section{Cellular Physiology Cell Physiol Biochem 2016;40:1506-1520 \begin{tabular}{ll|l} 
DOI: 10.1159/000453201 & $\begin{array}{l}\text { O 2016 The Author(s). Published by S. Karger AG, Basel } \\
\text { www.karger.com/cpb }\end{array}$
\end{tabular} \\ Mao et al.: Zedoarondiol Inhibits VSMCs Proliferation via AMPK}

Fig. 5. Zedoarondiol does not induce PDGF-BB-stimulated VSMCs apoptosis. VSMCs were double-stained with annexin $\mathrm{V}$ and PI to analyze apoptosis by flow cytometry. (A) Representative scatter plots of apoptosis. (B) Apoptotic rate was determined using the flow cytometry data. Data are expressed as mean $\pm \mathrm{SD} . \mathrm{n}=3 .{ }^{*} P<0.05$ vs. control; ${ }^{\#} P<0.05$ vs. PDGF.
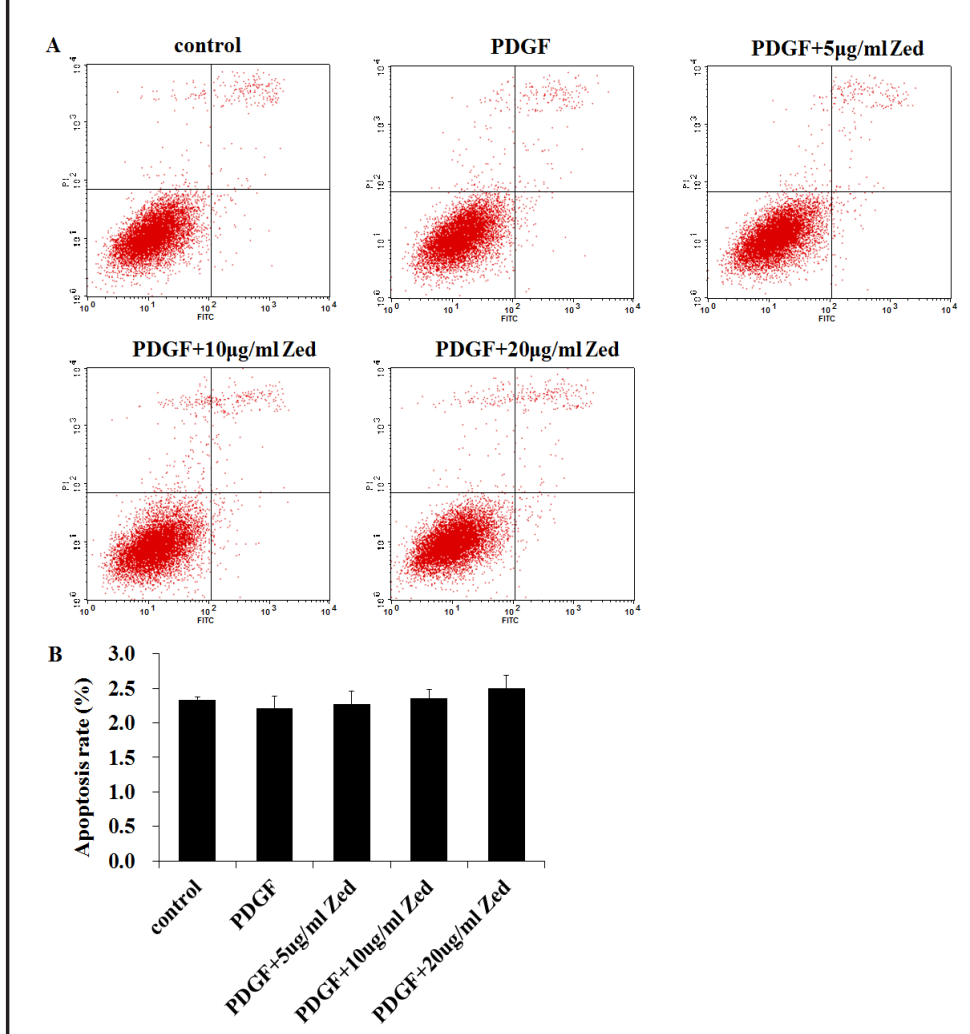

Zedoarondiol arrests VSMCs cell cycle in G0/G1 phase without accelerating apoptosis

Cell proliferation is tightly controlled by cell cycle progression. Thus, we investigated the effect of zedoarondiol on cell cycle progression by flow cytometry. As shown in Fig. 4, PDGF-BB significantly decreased the number of cells in G0/G1 phase from $88.85 \%$ to $71.79 \%(P<0.05$ vs. control), and increased the proportion of cells in S phase from $9.0 \%$ to $20.9 \%(P<0.05$ vs. control). Compared with PDGF group, Zedoarondiol pretreatment at 5 and $10 \mu \mathrm{g} / \mathrm{mL}$ had no effect on cell cycle $(P>0.05)$. However, pretreatment with $20 \mu \mathrm{g} / \mathrm{mL}$ zedoarondiol, followed by PDGF-BB stimulation, increased the proportion of cells in G0/G1 phase to $79.1 \%(P<0.05$ vs. PDGF $)$ and decreased the proportion of cells in $\mathrm{S}$ phase to $13.2 \%$ $(P<0.05$ vs. PDGF).

The reduction in cell number may result from inhibition of cell growth or induction of apoptosis. To investigate whether zedoarondiol induced PDGF-BB-stimulated VSMCs apoptosis, flow cytometry analysis was performed. The results showed no significant difference between groups $(P>0.05$; Fig. 5), indicating that the inhibitory effect of zedoarondiol on PDGF-BB-stimulated VSMCs was not associated with VSMCs apoptosis.

\section{Zedoarondiol induces the activation of AMPK}

To further illustrate the role of AMPK activation in zedoarondiol-mediated antiproliferative effects on VSMCs, the phosphorylation level of AMPK was examined. Compared with control group, zedoarondiol treatment alone did not affect AMPK phosphorylation $(P>0.05)$. Although PDGF-BB activated AMPK phosphorylation by $46 \%(P<0.05$ vs. control), its phosphorylation level was significantly lower than that observed in PDGF + Zed group $(P<0.05)$. However, compound $\mathrm{C}$ abolished this action, showing a $40.71 \%$ decrease in AMPK phosphorylation compared with PDGF + Zed group $(P<0.05)$. The pretreatment with zedoarondiol and AICAR further increased AMPK activation by $7.5 \%(P$ $<0.05$ vs. PDGF + Zed; Fig. 6A). In addition, we investigated the phosphorylation of ACC, a downstream target of AMPK. In accordance with AMPK activation, ACC phosphorylation was significantly activated in PDGF+Zed group, compared with PDGF group $(P<0.05)$. 


\section{Cellular Physiology Cell Physiol Biochem 2016;40:1506-1520 \begin{tabular}{ll|l} 
DOI: 10.1159/000453201 & O 2016 The Author(s). Published by S. Karger AG, Basel \\
and Biochemistry & Published online: Decemer 21, 2016 & margercom/cpb
\end{tabular}

Fig. 6. Zedoarondiol induces the activation of AMPK. VSMCs were pretreated with/without Zed (20 $\mu \mathrm{g} / \mathrm{mL})$, Zed+compound C $(10 \mu \mathrm{M})$ or Zed+AICAR $(0.5$ $\mathrm{mM}$ ) for $24 \mathrm{~h}$ and stimulated with/without PDGF-BB (20 ng/mL) for a further $24 \mathrm{~h}$. VSMCs were subjected to western blotting to determine the protein levels of (A) p-AMPK and AMPK (B) p-ACC and ACC. Protein levels were quantified by densitometry. GAPDH was used as an internal control. Data are expressed as mean \pm SD. $\mathrm{n}=3 .{ }^{*} P<0.05$ vs. control; ${ }^{\#} P<0.05$ vs. PDGF; ${ }^{\circledR} P<0.05$ vs. PDGF+Zed.

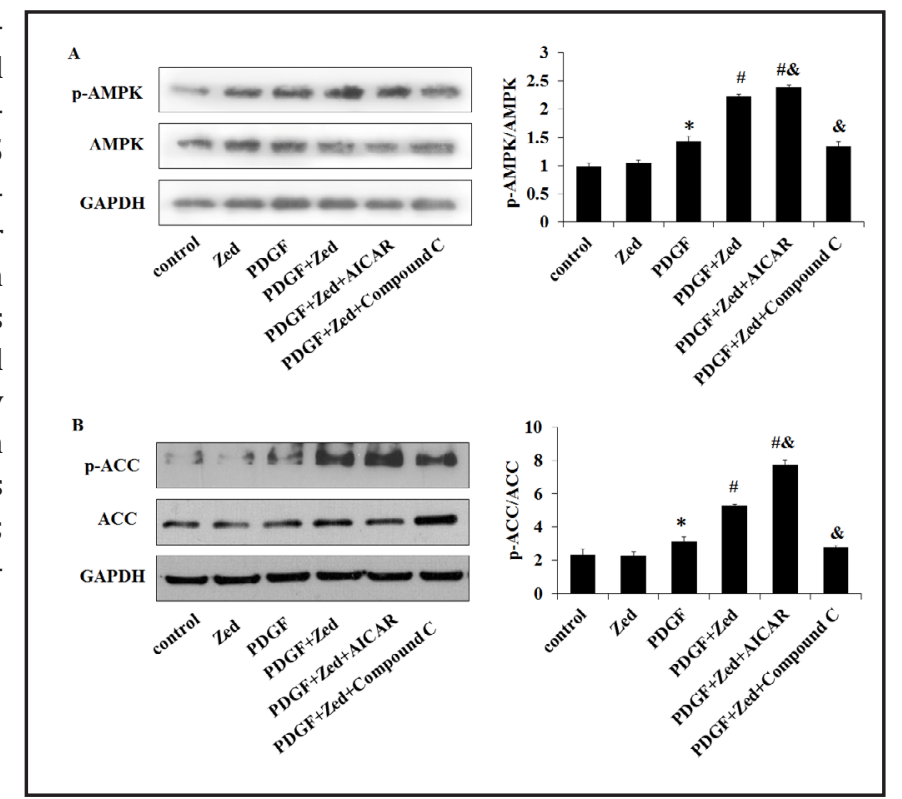

Fig. 7. Zedoarondiol down-regulates the mTOR/p70S6K signaling pathway. Western blotting was performed with antibodies specific for (A) p-mTOR and mTOR (B) p-p70S6 $\mathrm{K}^{\mathrm{Thr} 389}$ and p70S6K. Protein levels were quantified by densitometry. GAPDH was used as an internal control. Data are expressed as mean \pm SD. $\mathrm{n}=3$. ${ }^{*} P<0.05$ vs. control; ${ }^{\#} P<0.05$ vs. PDGF; ${ }^{\&} P<0.05$ vs. PDGF+Zed.

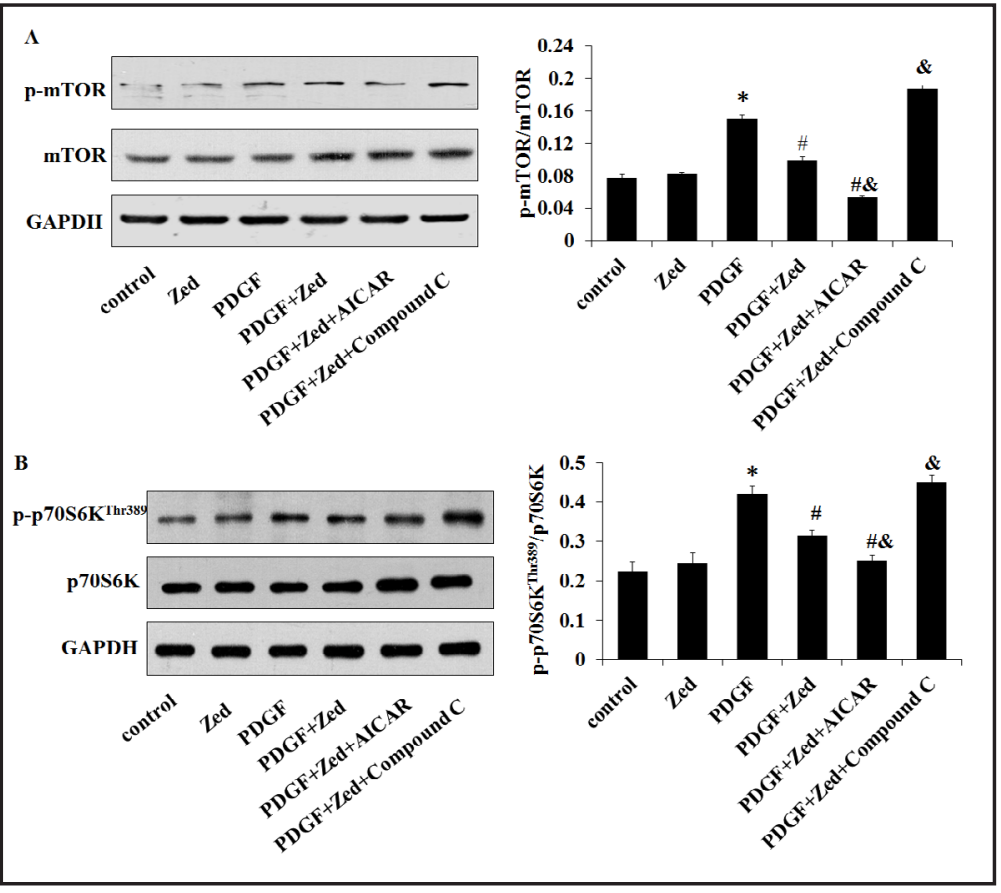

Additional treatment with compound $\mathrm{C}$ reversed zedoarondiol-mediated effects, resulting in a decrease in ACC phosphorylation. However, additional AICAR treatment further increased ACC phosphorylation $(P<0.05$ vs. PDGF + Zed; Fig. 6B). Our findings indicate that AMPK activation is involved in the anti-proliferative effects of zedoarondiol on VSMCs.

\section{Zedoarondiol down-regulates mTOR/p70S6K activity}

The mTOR/p70S6K pathway, a key downstream target of AMPK, is involved in the regulation of mitogen-induced VSMCs proliferation [32]. Therefore, we investigated whether the activity of mTOR/p70S6K was altered by zedoarondiol under PDGF-BB conditions. As shown in Fig. 7, zedoarondiol alone had no effect on the phosphorylation of mTOR and p70S6K at Thr389 compared with control group $(P>0.05)$. PDGF-BB significantly increased the phosphorylation of mTOR and p70S6K up to 1.96 and 1.91 fold, respectively $(P<0.05$ vs. control). However, compared with PDGF group, pretreatment with $20 \mu \mathrm{g} / \mathrm{mL}$ zedoarondiol 
Fig. 8. Zedoarondiol up-regulates the p53/ p21 pathway. Western blotting was performed with antibodies specific for p53 and p21. Protein levels were quantified by densitometry. GAPDH was used as an internal control. Data are expressed as mean \pm SD. $\mathrm{n}=3 .{ }^{*} P<0.05$ vs. control; ${ }^{\#} P<0.05$ vs. PDGF; ${ }^{\circledR} P<0.05$ vs. PDGF+Zed.

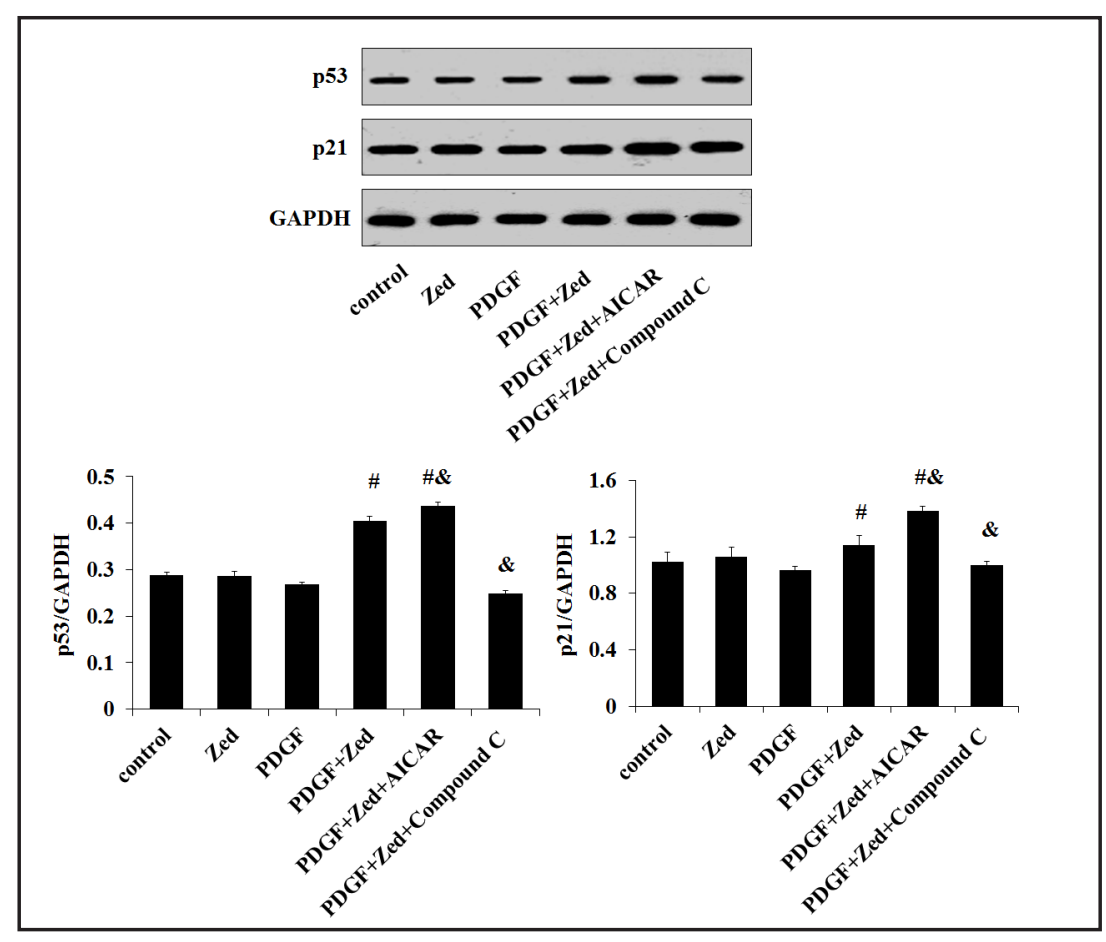

induced a $34.44 \%$ reduction in mTOR phosphorylation and a $23.81 \%$ reduction in p70S6K phosphorylation $(P<0.05)$. Compound $\mathrm{C}$ effectively reversed zedoarondiol-induced decrease in phosphorylation of mTOR and p70S6K by $89 \%$ and $41 \%$, respectively $(P<0.05$ vs. PDGF+Zed). Furthermore, in the presence of AICAR, the phosphorylation of mTOR and p70S6K at Thr389 further declined by $45.45 \%$ and $21.87 \%$, respectively, compared with PDGF+Zed group $(P<0.05)$.

Zedoarondiol up-regulates the $p 53 / p 21$ pathway

Cell cycle progression is controlled by cyclins/CDKs complexes, CDK inhibitors (CDKIs) and tumor suppressor genes. Recently, studies documented that AMPK activation is accompanied by the accumulation of p53, which, in turn, up-regulates p21 via a transcriptional mechanism [26, 33]. Therefore, we focused on the mechanisms of zedoarondiol-induced cell cycle arrest and determined whether the $\mathrm{p} 53 / \mathrm{p} 21$ pathway was involved in the zedoarondiolinduced inhibition of VSMCs proliferation. As shown in Fig. 8, PDGF-BB stimulation did not affect the expression of $\mathrm{p} 53$ and p 21 ( $P>0.05$ vs. control). When compared with PDGF group, zedoarondiol $(20 \mu \mathrm{g} / \mathrm{mL})$ pretreatment increased the expression of p53 and p21 by $52 \%$ and $18 \%$, respectively, under PDGF-BB conditions $(P<0.05)$. As expected, pretreatment with zedoarondiol and compound $\mathrm{C}$ abolished zedoarondiol-mediated increased expression of p53 and p21 under PDGF-BB conditions, resulting in a $39.27 \%$ and $12.28 \%$ decrease in p53 and p21 expression, respectively $(P<0.05$ vs. PDGF + Zed). Conversely, pretreatment with zedoarondiol and AICAR further increased the expression of p53 and p21 by 7\% and $22 \%$, respectively $(P<0.05$ vs. PDGF + Zed $)$.

CDK2 and cyclin E play a central role in regulating cell cycle transition from G1 to S phase. In addition, p21 down-regulates CDK2 and cyclin E, which is involved in cell cycle arrest [34]. We detected the protein levels of CDK2 and cyclin E by western blotting. PDGFBB markedly increased the expression of CDK2 and cyclin E by $30 \%$ and $84 \%$, respectively, compared with control group $(P<0.05)$. Zedoarondiol $(20 \mu \mathrm{g} / \mathrm{mL})$ pretreatment caused a $25.8 \%$ and $30.88 \%$ decrease in CDK2 protein and cyclin E protein expression, respectively, under PDGF-BB conditions ( $P<0.05$ vs. PDGF). However, zedoarondiol-mediated reduction of CDK2 and cyclin E expression was abolished by additional pretreatment with compound C, as shown by a $29 \%$ and $35 \%$ increase in CDK2 and cyclin E expression, respectively 
Fig. 9. Effects of zedoarondiol on expression of CDK2 and cyclin E. Western blotting was performed with antibodies specific for CDK2 and cyclin E. Protein levels were quantified by densitometry. GAPDH was used as an internal control. Data are expressed as mean \pm SD. $\mathrm{n}=3 .{ }^{*} P<0.05$ vs. control; ${ }^{\#} P<0.05$ vs. PDGF; ${ }^{\&} P<0.05$ vs. PDGF+Zed.

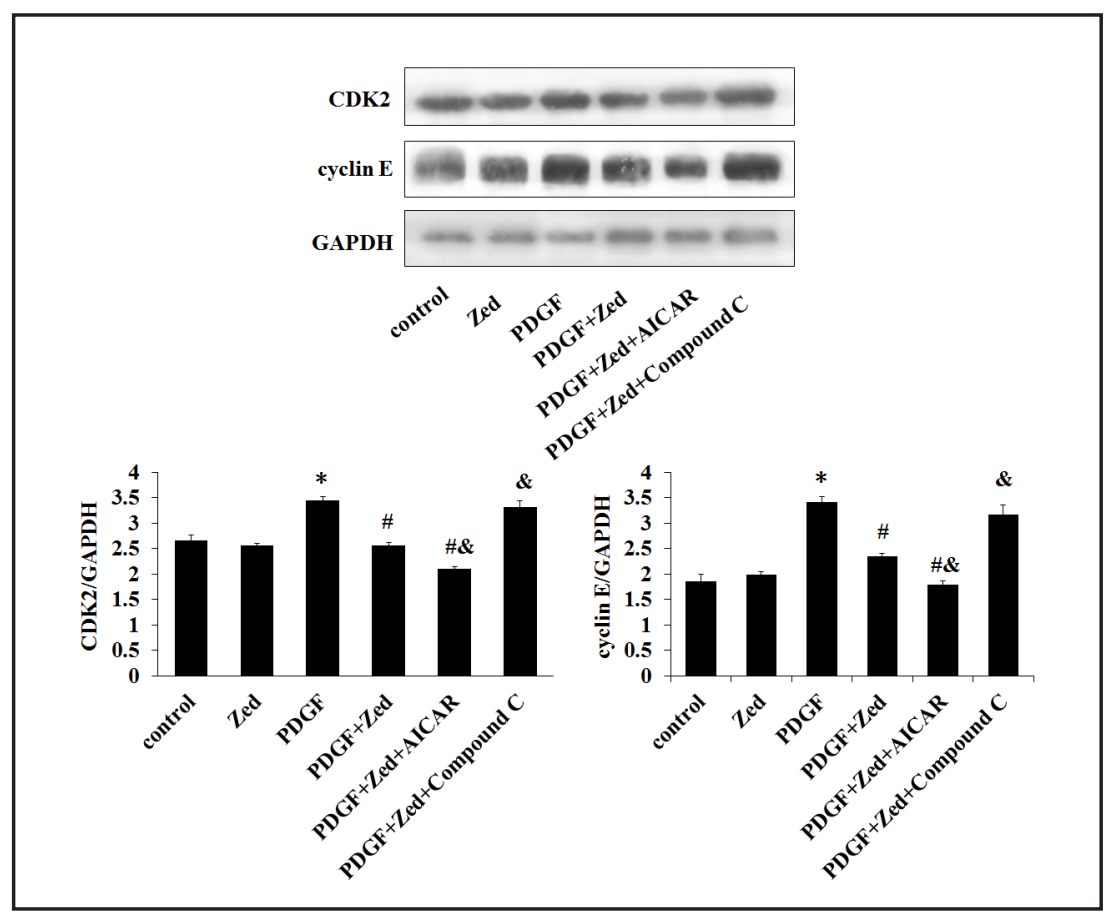

$(P<0.05$ vs. PDGF+Zed). In contrast, additional AICAR pretreatment aggravated zedoarondiolmediated inhibition of CDK2 and cyclin E expression ( $P<0.05$ vs. PDGF+Zed; Fig. 9).

\section{Discussion}

In this study, we investigated the effects of zedoarondiol on PDGF-BB-induced VSMCs proliferation and explored its possible mechanism. Our findings demonstrated that zedoarondiol suppressed VSMCs proliferation and DNA synthesis through AMPK activationmediated inhibition of mTOR/p70S6K and up-regulation of p53/p21, followed by VSMCs cycle arrest.

VSMCs proliferation plays an essential role in AS and RS [1, 2]. PDGF-BB is a potent mitogen released from injuried vessels, which contributes significantly to VSMCs proliferation. Therefore, it is a promising strategy to look for compounds which suppress PDGF-BB-mediated VSMCs proliferation [8]. Zedoarondiol is a sesquiterpenoid. Amounting evidence shows that sesquiterpenoids exhibit potent anti-tumor activities against HeLa cells, L615 cells, and hepatoma cells $[35,36]$. Our study demonstrated that zedoarondiol, the main compound extracted from ZEC, suppressed PDGF-BB-induced VSMCs proliferation and DNA synthesis, and caused cell cycle arrest in G0/G1 phase. These results may explain the previous reports of ZEC attenuating neointimal hyperplasia in a porcine coronary arterial balloon-injury model [17].

AMPK is a stress-activated protein kinase which serves as a cellular energy sensor [37]. AMPK activation suppresses neointimal formation in vascular injury models [23], and activation of AMPK inhibits VSMCs proliferation in vitro [26]. As a result, AMPK is considered as a promising novel target in the treatment of AS and RS. Many plant natural products, including berberine [38], sodium tanshinone IIA silate [39], and protocatechuic acid [40] have shown anti-proliferative effects on VSMCs via activating AMPK pathway. In the present study, we showed that the inhibitory effects of zedoarondiol on VSMCs proliferation induced by PDGF-BB were accompanied by AMPK activation, as evidenced by increased phosphorylation of AMPK and ACC. However, compound C, an inhibitor of AMPK, significantly reduced the anti-proliferative effects of zedoarondiol on VSMCs, whereas AICAR, an activator 
Fig. 10. Mechanisms of zedoarondiol-mediated inhibition of PDGF-BB-induced VSMCs proliferation. Zedoarondiol activates AMPK to inhibit the mTOR/p70S6K pathway, resulting in inhibition of protein synthesis. Activated AMPK up-regulates the p53/p21 pathway and induces cell cycle arrest. All effects described contribute to suppression of VSMCs proliferation.

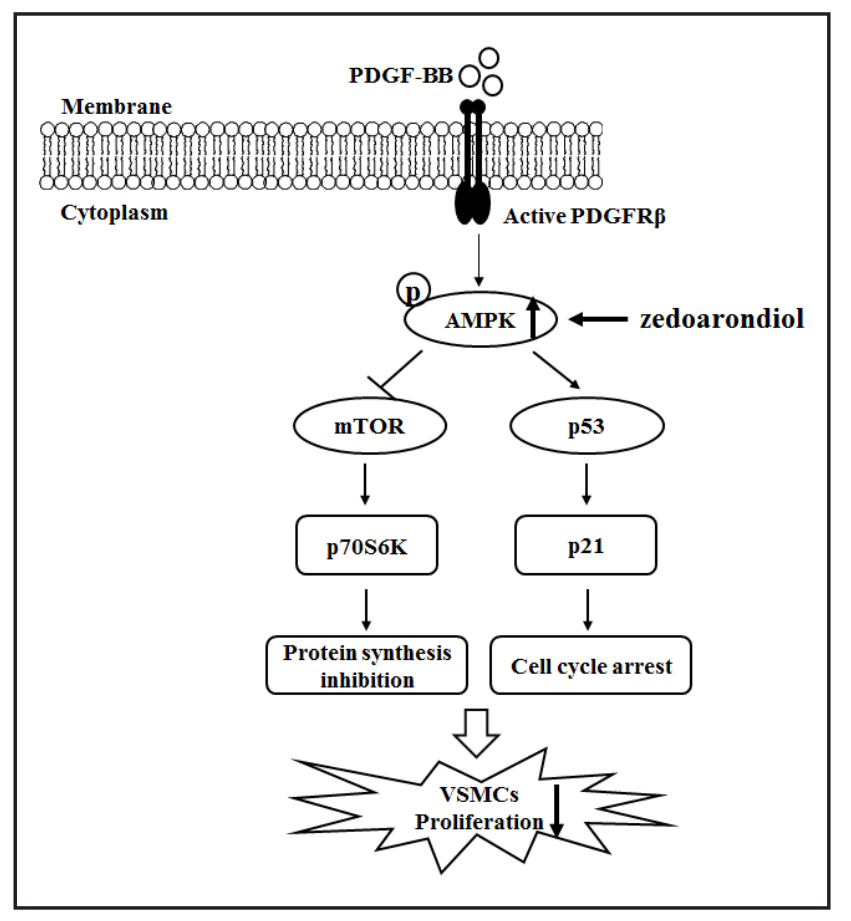

of AMPK, enhanced the zedoarondiol-induced inhibition of VSMCs proliferation. Therefore, our findings indicate that the anti-proliferative activity of zedoarondiol on PDGF-BB-induced VSMCs is associated with AMPK activation.

mTOR is an evolutionarily conserved serine/threonine kinase and a key downstream target of AMPK. The mTOR integrates nutrient and mitogen signals and acts as a vital regulator of protein synthesis, cell growth, cell division, and autophagy [41]. The most characterized downstream effector of mTOR is p70S6K, which is essential in activating several transcriptional factors, thereby regulating protein synthesis necessary for cell growth [42]. Increasing evidence indicates that the mTOR/p70S6K signaling pathway in VSMCs could be suppressed by AMPK activation, subsequently inhibiting VSMCs proliferation [43]. Our study revealed that zedoarondiol-medicated AMPK activation inhibited phosphorylation of mTOR and p70S6K at Thr389. As expected, compound C abolished zedoarondiol-mediated inhibition of mTOR and p70S6K phosphorylation, whereas AICAR further inhibited it, indicating that AMPK-mediated mTOR/p70S6K pathway inhibition is involved in the antiproliferative effects of zedoarondiol on PDGF-BB-stimulated VSMCs.

The cell cycle is governed positively by cyclins/CDKs complexes, and negatively by CDKIs and tumor suppressor genes [44]. The cyclin D/CDK4 and cyclin E/CDK2 complexes are required for cell cycle progression from G1 phase to the $S$ phase [45]. CDKIs, such as $\mathrm{p} 21^{\text {cip }}$ and p27 kip1, inhibit cyclin/CDKs activity, resulting in cell cycle arrested in G0/G1 phase [46]. Another vital negative regulator is tumor suppressor $\mathrm{p} 53$, which is an essential downstream target of AMPK. Increased expression of p53 induces cell cycle arrest and/or apoptosis by modulating CDKs and CDKIs $[47,48]$. Previous studies have shown that AMPK activation upregulates the expression of p53 and p21 and down-regulates the expression cyclin E/CDK2, thus preventing cell cycle progression into S phase [49]. In this study, zedoarondiol upregulated the protein expression of $\mathrm{p} 53$ and $\mathrm{p} 21$ and down-regulated the protein expression of cyclin E and CDK2 under PDGF-BB conditions, which was abrogated by compound C but aggravated by AICAR. ElKeeb et al. reported that increased p53 expression induced cell cycle arrest and apoptosis [50]. However, in this study, zedoarondiol-induced up-regulated p53 did not trigger apoptosis in VSMCs. Taken together, these results indicate that AMPKmediated up-regulation of $\mathrm{p} 53 / \mathrm{p} 21$ pathway is associated with the anti-proliferative effects of zedoarondiol on PDGF-BB-stimulated VSMCs.

\section{KARGER}




\section{Cellular Physiology Cell Physiol Biochem 2016;40:1506-1520 \begin{tabular}{l|l|l|} 
and BOI: 10.1159/000453201 & $\begin{array}{l}\text { C) 2016 The Author(s). Published by S. Karger AG, Basel } \\
\text { www.karger.com/cpb }\end{array}$
\end{tabular} \\ Mao et al.: Zedoarondiol Inhibits VSMCs Proliferation via AMPK}

Although the present study indicates the anti-proliferative effects of zedoarondiol on VSMCs, several limitations should be pointed out. First, AICAR is a non-selective activator of AMPK [51], which might elicit AMPK-independent effects. A more specific AMPK activator, such as A769662, or metabolic/endogenous stimulation should be adopted to activate AMPK in future studies, to further determine the role of AMPK in zedoarondiol-mediated effects. Second, in the present study, GAPDH was used to normalize protein expression in western blotting. Zedoarondiol is a sesquiterpenoid compound. Numerous studies evaluating sesquiterpenoids on VSMCs indicate that GADPH is widely used as a normalization control in western blotting and that GADPH expression appears unchanged with sesquiterpenoids treatment $[52,53]$. Based on these findings, we chose GADPH to normalize protein expression in our study. Given that zedoarondiol has been untested in VSMCs before, whether GADPH expression remains unchanged with zedoarondiol needs to be investigated. Third, we did not evaluate the effect of compound C alone on VSMCs proliferation and AMPK phosphorylation. Previous studies have indicated that compound $\mathrm{C}$ alone does not affect VSMCs proliferation and inhibits AMPK phosphorylation in VSMCs $[38,54]$. To further solidify the results from our study, the effect of compound C alone on VSMCs proliferation and AMPK phosphorylation should be incorporated in our future studies. Moreover, the time-dependent effects of zedoarondiol on AMPK phosphorylation were not investigated in our study. Thus, the present study did not clarify which time point after zedoarondiol treatment has the most favorable effect on the phosphorylation of AMPK. In the future, we will conduct the time-dependent study on AMPK phosphorylation, in order to provide more precise information of the role of zedoarondiol in VSMCs proliferation induced by PDGF-BB.

In conclusion, our study demonstrated that zedoarondiol, a sesquiterpene lactone compound extracted from Zedoariae rhizoma, inhibits VSMCs proliferation induced by PDGF-BB. The underlying mechanisms of zedoarondiol-mediated anti-proliferative effects are associated with AMPK activation, subsequently inhibiting the mTOR/p70S6K signaling pathway and up-regulating the p53/p21 pathway (Fig. 10). Our findings suggest that zedoarondiol might be a promising compound against VSMCs proliferation-related diseases, such as AS and RS.

\section{Acknowledgements}

This work was supported by the grant from National Science-Technology Support Plan of China (No. 2013BAI02B01), the National Basic Research Program of China (2015CB554402), and the National Natural Science Foundation of China (81473530).

\section{Disclosure Statement}

The authors report no conflicts of interest.

\section{References}

1 Chistiakov DA, Orekhov AN, Bobryshev YV: Vascular smooth muscle cell in atherosclerosis. Acta Physiol (Oxf) 2015;214:33-50.

2 Marx SO, Totary-Jain H, Marks AR: Vascular smooth muscle cell proliferation in restenosis. Circ Cardiovasc Interv 2011;4:104-111.

3 Donovan J, Abraham D, Norman J: Platelet-derived growth factor signaling in mesenchymal cells. Front Biosci (Landmark Ed) 2013;18:106-119.

4 Iida M, Tanabe K, Kozawa O, Iida H: Differential effects of intravenous anesthetics on PDGF-BB-induced vascular smooth muscle cell migration. Cell Physiol Biochem 2014;33:1827-1837. 


\section{Cellular Physiology Cell Physiol Biochem 2016;40:1506-1520 \begin{tabular}{l|l|l} 
and Biochemistry & DOI: 10.1159/000453201 & $\begin{array}{l}\text { C } 2016 \text { The Author(s). Published by S. Karger AG, Basel } \\
\text { www.karger.com/cpb }\end{array}$
\end{tabular} \\ Mao et al.: Zedoarondiol Inhibits VSMCs Proliferation via AMPK}

5 Eun SY, Ko YS, Park SW, Chang KC, Kim HJ: IL-1 $\beta$ enhances vascular smooth muscle cell proliferation and migration via P2Y2 receptor-mediated RAGE expression and HMGB1 release. Vascul Pharmacol 2015;72:108-117.

6 Jiang F, Jiang R, Zhu X, Zhang X, Zhan Z: Genipin inhibits TNF- $\alpha$-induced vascular smooth muscle cell proliferation and migration via induction of HO-1. Plos One 2013;8:e74826.

7 Bihl JC, Zhang C, Zhao Y, Xiao X, Ma X, Chen Y, Chen S, Zhao B, Chen Y: Angiotensin-(1-7) counteracts the effects of Ang II on vascular smooth muscle cells, vascular remodeling and hemorrhagic stroke: Role of the NFKB inflammatory pathway. Vascul Pharmacol 2015;73:115-123.

8 Ricci C, Ferri N: Naturally occurring PDGF receptor inhibitors with potential anti-atherosclerotic properties. Vascul Pharmacol 2015;70:1-7.

9 Yu L, Huang X, Huang K, Gui C, Huang Q, Wei B: Ligustrazine attenuates the platelet-derived growth factorBB-induced proliferation and migration of vascular smooth muscle cells by interrupting extracellular signal-regulated kinase and P38 mitogen-activated protein kinase pathways. Mol Med Rep 2015;12:705711.

10 Lee MH, Kwon BJ, Seo HJ, Yoo KE, Kim MS, Koo MA, Park JC: Resveratrol inhibits phenotype modulation by platelet derived growth factor-bb in rat aortic smooth muscle cells. Oxid Med Cell Longev 2014;2014:572430.

11 Zhao Y, Lv M, Lin H, Hong Y, Yang F, Sun Y, Guo Y, Cui Y, Li S, Gao Y: ROCK1 induces ERK nuclear translocation in PDGF-BB-stimulated migration of rat vascular smooth muscle cells. IUBMB Life 2012;64:194-202.

12 Ha JM, Yun SJ, Kim YW, Jin SY, Lee HS, Song SH, Shin HK, Bae SS: Platelet-derived growth factor regulates vascular smooth muscle phenotype via mammalian target of rapamycin complex 1. Biochem Biophys Res Commun 2015;464:57-62.

13 Ma JH, Wang Y, Liu Y, Gao SY, Ding LQ Zhao F, Chen LX, Qiu F: Four new sesquiterpenes from the rhizomes of Curcuma phaeocaulis and their iNOS inhibitory activities. J Asian Nat Prod Res 2015;17:532-540.

14 Yang X, Thomas DP, Zhang X, Culver BW, Alexander BM, Murdoch WJ, Rao MN, Tulis DA, Ren J, Sreejayan $\mathrm{N}$ : Curcumin inhibits platelet-derived growth factor-stimulated vascular smooth muscle cell function and injury-induced neointima formation. Arterioscler Thromb Vasc Biol 2006;26:85-90.

15 Kim DI, Lee TK, Jang TH, Kim CH: The inhibitory effect of a Korean herbal medicine, Zedoariae rhizoma, on growth of cultured human hepatic myofibroblast cells. Life Sci 2005;77:890-906.

16 Tao QF, Xu Y, Lam RY, Schneider B, Dou H, Leung PS, Shi SY, Zhou CX, Yang LX, Zhang RP, Xiao YC, Wu X, Stöckigt J, Zeng S, Cheng CH, Zhao Y: Diarylheptanoids and a monoterpenoid from the rhizomes of Zingiber officinale: antioxidant and cytoprotective properties. J Nat Prod 2008;71:12-17.

17 Zhao FH, Liu JG, Wang X, Zhang DW, Wang PL, Zhang L, Du JP, Li XZ, Ma YL, Shi Y, Shi DZ: Long-term effect of stent coating with zedoary essential components on neointimal formation in the porcine coronary artery. Chin J Integr Med 2013;19:771-776.

18 Cho W, Nam JW, Kang HJ, Windono T, Seo EK, Lee KT: Zedoarondiol isolated from the rhizoma of Curcuma heyneana is involved in the inhibition of iNOS, COX-2 and pro-inflammatory cytokines via the downregulation of NF-kappaB pathway in LPS-stimulated murine macrophages. Int Immunopharmacol 2009;9:1049-1057.

19 Matsuda H, Ninomiya K, Morikawa T, Yoshikawa M: Inhibitory effect and action mechanism of sesquiterpenes from Zedoariae Rhizoma on D-galactosamine/lipopolysaccharide-induced liver injury. Bioorg Med Chem Lett 1998;8:339-344.

20 Morikawa T, Matsuda H, Ninomiya K, Yoshikawa M: Potent protective effects of sesquiterpenes and curcumin from Zedoariae Rhizoma on liver injury induced by D-galactosamine/lipopolysaccharide or tumor necrosis factor-alpha. Biol Pharm Bull 2002;25:627-631.

21 Hardie DG. Minireview: the AMP-activated proteinkinase cascade: the key sensor of cellular energy status. Endocrinology 2003;144:5179-5183.

22 Kemp BE, Stapleton D, Campbell DJ, Chen ZP, Murthy S, Walter M, Gupta A, Adams JJ, Katsis F, van Denderen B, Jennings IG, Iseli T, Michell BJ, Witters LA: AMP-activated protein kinase, super metabolic regulator. Biochem Soc Trans 2003;31:162-168.

23 Nagata D, Takeda R, Sata M, Satonaka H, Suzuki E, Nagano T, Hirata Y: AMP-activated protein kinase inhibits angiotensin II-stimulated vascular smooth muscle cell proliferation. Circulation 2004;110:444-451. 


\section{Cellular Physiology Cell Physiol Biochem 2016;40:1506-1520 \begin{tabular}{l|l|l} 
and BOI: 10.1159/000453201 & $\begin{array}{l}\text { (c) 2016 The Author(s). Published by S. Karger AG, Basel } \\
\text { www.karger.com/cpb }\end{array}$
\end{tabular} \\ Mao et al.: Zedoarondiol Inhibits VSMCs Proliferation via AMPK}

24 Ki SH, Lee JW, Lim SC, Hien TT, Im JH, Oh WK, Lee MY, Ji YH, Kim YG, Kang KW: Protective effect of nectandrin $\mathrm{B}$, a potent AMPK activator on neointima formation: inhibition of Pin1 expression through AMPK activation. Br J Pharmacol 2013;168:932-945.

25 Stone JD, Narine A, Shaver PR, Fox JC, Vuncannon JR, Tulis DA: AMP-activated protein kinase inhibits vascular smooth muscle cell proliferation and migration and vascular remodeling following injury. Am J Physiol Heart Circ Physiol 2013;304:H369-381.

26 Hiroyuki Motoshima, Barry J. Goldstein, Motoyuki Igata, Araki E: AMPK and cell proliferation-AMPK as a therapeutic target for atherosclerosis and cancer. J Physiol 2006;574:63-71.

27 Igata M, Motoshima H, Tsuruzoe K, Kojima K, Matsumura T, Kondo T, Taguchi T, Nakamaru K, Yano M, Kukidome D, Matsumoto K, Toyonaga T, Asano T, Nishikawa T, Araki E: Adenosine monophosphateactivated protein kinase suppresses vascular smooth muscle cell proliferation through the inhibition of cell cycle progression. Circ Res 2005;97:837-844.

28 Kim EJ, Choi YK, Han YH, Kim HJ, Lee IK, Lee MO: ROR $\alpha$ suppresses proliferation of vascular smooth muscle cells through activation of AMP-activated protein kinase. Int J Cardiol 2014;175:515-521.

29 Lee WR, Kim A, Kim KS, Park YY, Park JH, Kim KH, Kim SJ, Park KK: Alpha-lipoic acid attenuates atherosclerotic lesions and inhibits proliferation of vascular smooth muscle cells through targeting of the Ras/MEK/ERK signaling pathway. Mol Biol Rep 2012;39:6857-6866.

30 Yao Y, Zhang YW, Sun LG, Liu B, Bao YL, Lin H, Zhang Y, Zheng LH, Sun Y, Yu CL, Wu Y, Wang GN, Li YX: Juglanthraquinone $\mathrm{C}$, a novel natural compound derived from Juglans mandshurica Maxim, induces $\mathrm{S}$ phase arrest and apoptosis in HepG2 cells. Apoptosis 2012;17:832-841.

31 Walker JM: The bicinchoninic acid (BCA) assay for protein quantitation. Methods Mol Biol 1994;32:5-8.

32 Kang JI, Hong JY, Lee HJ, Bae SY, Jung C, Park HJ, Lee SK: Anti-Tumor Activity of Yuanhuacine by Regulating AMPK/mTOR Signaling Pathway and Actin Cytoskeleton Organization in Non-Small Cell Lung Cancer Cells. Plos One 2015;10:e0144368.

33 Sung JY, Woo CH, Kang YJ, Lee KY, Choi HC: AMPK induces vascular smooth muscle cell senescence via LKB1 dependent pathway. Biochem Biophys Res Commun 2011;413:143-148.

34 Harper JW, Elledge SJ, Keyomarsi K, Dynlacht B, Tsai LH, Zhang P, Dobrowolski S, Bai C, Connell-Crowley L, Swindell E: Inhibition of cyclin-dependent kinases by p21. Mol Biol Cell 1995;6:387-400.

35 Wang GW, Qin JJ, Cheng XR, Shen YH, Shan L, Jin HZ, Zhang WD: Inula sesquiterpenoids: structural diversity, cytotoxicity and anti-tumor activity. Expert Opin Investig Drugs 2014;23:317-345.

36 Xiao Y, Yang FQ, Li SP, Hu G, Lee SM, Wang YT: Essential oil of Curcuma wenyujin induces apoptosis in human hepatoma cells. World J Gastroenterol 2008;14:4309-4018.

37 Hardie DG, Carling D, Carlson M: The AMP-activated/SNF1 proteinkinase subfamily: metabolic sensors of the eukaryotic cell? Annu RevBiochem 1998;67:821-855.

38 Liang KW, Yin SC, Ting CT, Lin SJ, Hsueh CM, Chen CY, Hsu SL: Berberine inhibits platelet-derived growth factor-induced growth and migration partly through an AMPK-dependent pathway in vascular smooth muscle cells. Eur J Pharmacol 2008;590:343-354.

39 Wu WY, Yan H, Wang XB, Gui YZ, Gao F, Tang XL, Qin YL, Su M, Chen T, Wang YP: Sodium tanshinone IIA silate inhibits high glucose-induced vascular smooth muscle cell proliferation and migration through activation of AMP-activated protein kinase. Plos One 2014;9:e94957.

40 Lin MC, Ou TT, Chang CH, Chan KC, Wang CJ: Protocatechuic acid inhibits oleic acid-induced vascular smooth muscle cell proliferation through activation of AMP-activated protein kinase and cell cycle arrest in G0/G1 phase. J Agric Food Chem 2015;63:235-241.

41 Laplante M, Sabatini DM: mTOR signaling in growth control and disease. Cell 2012;149:274-293.

42 Fingar DC, Blenis J: Target of rapamycin (TOR): an integrator of nutrient and growth factor signals and coordinator of cell growth and cell cycle progression. Oncogene 2004;23:3151-3171.

43 Osman I, Segar L: Pioglitazone, a PPAR $\gamma$ agonist, attenuates PDGF-induced vascular smooth muscle cell proliferation through AMPK-dependent and AMPK-independent inhibition of mTOR/p70S6K and ERK signaling. Biochem Pharmacol 2016;101:54-70.

44 Sherr CJ: Cancer cell cycles. Science 1996;274:1672-1677.

45 Andres V: Control of vascular cell proliferation and migration by cyclin-dependent kinase signalling: new perspectives and therapeutic potential. Cardiovasc Res 2004;63:11-21. 


\section{Cellular Physiology Cell Physiol Biochem 2016;40:1506-1520 \begin{tabular}{l|l|l} 
DOI: 10.1159/000453201 & $\begin{array}{l}\text { O 2016 The Author(s). Published by S. Karger AG, Basel } \\
\text { www.karger.com/cpb }\end{array}$
\end{tabular} \\ Mao et al.: Zedoarondiol Inhibits VSMCs Proliferation via AMPK}

46 Tanner FC, Boehm M, Akyürek LM, San H, Yang ZY, Tashiro J, Nabel GJ, Nabel EG: Differential effects of the cyclin-dependent kinase inhibitors p27 (Kip1), p21 (Cip1), and p16 (Ink4) on vascular smooth muscle cell proliferation. Circulation 2000;101:2022-2025.

47 Kreis NN, Louwen F, Yuan J: Less understood issues: p21(Cip1) in mitosis and its therapeutic potential. Oncogene 2015;34:1758-1767.

48 Rattan R, Giri S, Singh AK, Singh I: 5-Aminoimidazole-4-carboxamide-1-beta-D-ribofuranoside inhibits cancer cell proliferation in vitro and in vivo via AMP-activated protein kinase. J Biol Chem 2005;280:3958239593.

49 Lee KY, Lee DH, Choi HC: Mesoglycan attenuates VSMC proliferation through activation of AMP-activated protein kinase and mTOR. Clin Hypertens 2016;22:2.

50 ElKeeb AM, Collier ME, Maraveyas A, Ettelaie C: Accumulation of tissue factor in endothelial cells induces cell apoptosis, mediated through p38 and p53 activation. Thromb Haemost 2015;114:364-378.

51 Sid B, Glorieux C, Valenzuela M, Rommelaere G, Najimi M, Dejeans N, Renard P, Verrax J, Calderon PB: AICAR induces Nrf2 activation by an AMPK-independent mechanism in hepatocarcinoma cells. Biochem Pharmacol 2014;91:168-180.

52 Kim N, Hwangbo C, Lee S, Lee JH: Eupatolide inhibits PDGF-induced proliferation and migration of aortic smooth muscle cells through ROS-dependent heme oxygenase-1 induction. Phytother Res 2013;27:17001707.

53 Lee KP, Park ES, Kim DE, Park IS, Kim JT, Hong H: Artemisinin attenuates platelet-derived growth factor BBinduced migration of vascular smooth muscle cells. Nutr Res Pract 2014;8:521-525.

54 Huang X, Fan R, Lu Y, Yu C, Xu X, Zhang X, Liu P, Yan S, Chen C, Wang L: Regulatory effect of AMP-activated protein kinase on pulmonary hypertension induced by chronic hypoxia in rats: in vivo and in vitro studies. Mol Biol Rep 2014;41:4031-4041. 